\title{
Determination of the appropriate level of salinity for screening of hydroponically grown rice for salt tolerance
}

\author{
W.A.J.M. De Costa, M.A.D. Wijeratne, D.M. De Costa and A.R.F. Zahra \\ Department of Crop Science, Faculty of Agriculture, University of Peradeniya, Peradeniya.
}

Revised: 12 December 2011 ; Accepted: 20 January 2012

\begin{abstract}
Development of salt tolerant rice varieties has become an urgent priority because of the increase of salinity in rice lands. The objectives of the present experiment were to determine: (a) the appropriate level of salt stress to be imposed for screening rice varieties grown in hydroponics for salt tolerance at Phase I (osmotic stress) and at Phase II (salt ion toxicity) of salt stress development; (b) the point of transition from Phase I to II and (c) the degree of salt tolerance in the Sri Lankan improved rice variety At354 in comparison to the known salt-tolerant rice variety, Pokkali. Seedlings of the two varieties were grown in a plant house in nutrient solutions in a range of salt concentrations, i.e. 1 (Control), 20, 40, 60, 80, 100, 120 and $150 \mathrm{mM} \mathrm{NaCl}$. Area of the youngest fully-expanded leaf at salt stress commencement and at 2-7 day intervals was measured non-destructively. The total plant biomass was measured after 30 days of salt stress. Based on the time courses of relative area of the youngest fully-expanded leaf $\mathrm{RL}_{\mathrm{A}}$ (i.e. area of the leaf under salt stress as a proportion of that in the control), $100 \mathrm{mM} \mathrm{Na}^{+}$was determined as the optimum salinity level for varietal screening. At $100 \mathrm{mM} \mathrm{Na}^{+}$, the two phases could be identified clearly, with Phase I (from 0 to 10 days after reaching $100 \mathrm{mM} \mathrm{Na}^{+}$) showing a significantly lower rate of reduction of $\mathrm{RL}_{\mathrm{A}}$ than Phase II (starting after 10 days). The Sri Lankan improved rice variety At354 showed lower rates of reduction of relative plant biomass and $\mathrm{RL}_{\mathrm{A}}$ and a slower rate of $\mathrm{Na}^{+}$accumulation in the shoot in comparison to Pokkali with increasing salt stress, demonstrating its greater salt tolerance than that of Pokkali.
\end{abstract}

Keywords: At354, Pokkali, rice, salt-stress, two-phase model.

\section{INTRODUCTION}

Increasing salt ion concentration in the soil solution, commonly known as 'salinity', is becoming an important stress factor causing significant reduction in the productivity of agricultural crops, both globally (Szabolcs, 1994; Pitman \& Läuchli, 2002; Munns \& Tester, 2008) and in Sri Lanka (Sirisena \& Herath, 2009). In agriculture, a soil having a salt concentration exceeding an electrical conductivity (EC) value of $4 \mathrm{dS} \mathrm{m}^{-1}$ is classified as saline (USDA-ARS, 2008). This is based on the observation that the yield of most crops is reduced at salinity levels above $4 \mathrm{dS} \mathrm{m}^{-1}$, which is equivalent to $40 \mathrm{mM} \mathrm{NaCl}$ and an osmotic pressure of 0.2 MPa. Rice (Oryza sativa L.) is the staple food of more than 1 billion people worldwide, which includes 20 million people in Sri Lanka. The sensitivity to salinity differs between different crop species and rice is classified as one of the most sensitive crops (Maas \& Hoffman, 1977; Munns \& Tester, 2008).

High concentrations of salts in irrigation water, (Ghassemi et al., 1995), global warming-induced sea level rise (IPCC, 2007) and increased evapotranspiration rates (De Costa, 2009), which bring greater amounts of salts to the soil surface could contribute to increased salinity levels in rice lands in the future. Out of the 160 million ha of rice grown worldwide, nearly 80 million ha are grown under irrigation (IRRI, 2011). Seventy five percent of the 720,000 ha of rice in Sri Lanka is cultivated under irrigation (IRRI, 2010). Irrigated lands have higher productivity in comparison to rainfed lands. The effect of increasing salinity levels in irrigated rice lands on total rice production, will therefore be proportionately greater. Out of the total annual extent of rice-cultivated in Sri Lanka, nearly $70 \%$ of the coastal rice lands are reported to be affected by salinity (Anonymous, 2011). Therefore, it is imperative that salt-tolerant rice varieties are developed in Sri Lanka.

* Corresponding author (janendrad@yahoo.com) 
Traditional rice varieties, Pokkali and Nona Bokra, which originated in the coastal zones of India, have been identified as salt-tolerant and used extensively worldwide for research on salt-tolerance in rice (Munns et al., 2006). However, these varieties are low-yielding because of their tall plant type and droopy-leaved canopy architecture. Rice breeders at the Rice Research and Development Institute of the Department of Agriculture of Sri Lanka have been successful in breeding several rice varieties, which combine comparative salt-tolerance with mediumto-high yield. The most prominent among these is the variety At354, which is a $3 \frac{1}{2}$-month variety with dwarf and erect-leaved canopy architecture and a yield potential (i.e. the yield under optimum environmental and growing conditions) of $10 \mathrm{t} \mathrm{ha}^{-1}$ and a potential yield of $5 \mathrm{t} \mathrm{ha}^{-1}$ under saline conditions. At354 has been developed from a cross between Pokkali and the high-yielding, dwarf and erect-leaved variety Bg94-1.

Plants respond to salinity in two phases (Munns 1993; Munns et al., 1995). During the initial phase (Phase I), excess salts in the external soil solution makes water less available for absorption through plant roots, due to binding with water molecules, thus reducing plant growth. Salinity-induced growth reduction in Phase I is followed by a gradual accumulation of salts in plant tissue, first in the older tissue and then in the younger tissue along with the absorption of saline water leading to salt-ion toxicity. This is Phase II of salt-stress development and is characterized by tissue senescence proceeding from older to younger tissues (i.e. leaves).

It follows from the two-phase model of salt-stress development that tolerance to salinity requires different physiological mechanisms during the two phases. Salttolerance during Phase I requires tolerance to osmotic stress, while tolerance during Phase II requires exclusion of toxic salt ions from important tissues such as leaves and tolerance of tissues to high salt concentrations through cellular and intra-cellular compartmentalization (Munns \& Tester, 2008). It is highly likely that these different physiological mechanisms of salt tolerance during different phases are controlled by different genes, which may be expressed to different degrees in different genotypes. Therefore, varietal screening of rice needs to be carried out separately for the two phases of salt stress development, so that the varieties/genotypes/accessions that are tolerant to osmotic stress (during Phase I) and salt ion toxicity (during Phase II) can be identified separately (Munns et al., 2002).

Therefore, an important requirement in the varietal screening for salt tolerance is to determine the appropriate level of salinity that should be used for screening. When deciding on an appropriate level of salinity for varietal screening, the following have to be considered. Firstly, the selected level of salinity should be high enough to detect varieties, that have an adequate degree of tolerance. A salinity level that is not high enough would detect varieties, which do not have an adequate degree of tolerance, as tolerant. Secondly, in order to identify varieties that are tolerant in the two phases of salt stress development separately, the selected level of salinity needs to be 'low' enough for the two phases to be adequately separated in time. This would allow the researchers enough time to collect plant samples in the two phases. The present experiment was designed to hydroponically screen the two known salt tolerant rice varieties (i.e. Pokkali and At354) using a series of salinity levels ranging from 20 to $150 \mathrm{mM} \mathrm{Na}^{+}$with the objective to determine: (a) the appropriate level of salt stress to be imposed for screening rice varieties in hydroponics for tolerance to salinity in the two phases of salt stress development; (b) the point at which Phase I of salt stress development (i.e. osmotic stress) shifts to Phase II of salt stress development (i.e. salt-ion toxicity) and (c) the degree of salt tolerance in the Sri Lankan improved rice variety At354 in comparison to the standard salt-tolerant rice variety, Pokkali. In order to determine the appropriate level of salt stress to be imposed for screening for salt tolerance, the known tolerant varieties had to be used as benchmarks. Use of moderately-tolerant or susceptible varieties for the above purpose would result in a lower level of salinity being selected as appropriate, thus identifying even moderately tolerant varieties as tolerant varieties. This would not bring about any improvement in salt tolerance in rice because the new salt tolerant varieties would only be useful if they have a greater tolerance than the existing tolerant varieties.

\section{METHODS AND MATERIALS}

Experimental location: The experiment was conducted in a rain-sheltered, ventilated plant house at the Agricultural Biotechnology Centre, University of Peradeniya, Peradeniya (Latitude $7^{\circ} 15^{\prime} 47 \mathrm{~N}$, Longitude $80^{\circ} 36^{\prime} 10 \mathrm{E}$, Altitude $496 \mathrm{~m}$ above sea level).

Plant material: The two known salt-tolerant rice varieties, At354 and Pokkali were used in this experiment. The seeds were obtained from the Plant Genetic Resources Centre of the Department of Agriculture, Gannoruwa, Peradeniya.

Plant culture and experimental treatments: Plants were grown hydroponically in aerated nutrient solutions. A 
specific nutrient solution that had been used for hydroponic culture of rice (Yoshida et al., 1972) was used. The composition of the full-strength nutrient solution was: (in $\mathrm{gL}^{-1}$ ) $\mathrm{NH}_{4} \mathrm{NO}_{3}, 91.4 ; \mathrm{NaH}_{2} \mathrm{PO}_{2} .2 \mathrm{H}_{2} \mathrm{O}, 40.3 ; \mathrm{K}_{2} \mathrm{SO}_{4}$, 71.4; $\mathrm{MgSO}_{4} .7 \mathrm{H}_{2} \mathrm{O}, 324 ; \mathrm{CaCl}_{2}, 88.6 ; \mathrm{MnCl}_{2} .4 \mathrm{H}_{2} \mathrm{O}$, 1.5; $\left(\mathrm{NH}_{4}\right)_{6} \cdot \mathrm{Mo}_{7} \mathrm{O}_{24} \cdot 4 \mathrm{H}_{2} \mathrm{O}, 0.074 ; \mathrm{H}_{3} \mathrm{BO}_{3}, \mathrm{ZnSO}_{4} \cdot 7 \mathrm{H}_{2} \mathrm{O}$, $0.035 ; \mathrm{CuSO}_{4} .5 \mathrm{H}_{2} \mathrm{O}, 0.031 ; \mathrm{FeCl}_{3} \cdot 6 \mathrm{H}_{2} \mathrm{O}, 7.7$; and Citric acid, 11.9. Micronutrient salts were dissolved separately and combined with $50 \mathrm{~mL}$ conc. $\mathrm{H}_{2} \mathrm{SO}_{4}$ and the volume adjusted to $1 \mathrm{~L}$ by distilled water. $\mathrm{pH}$ of the final culture solution was maintained at 5 . The nutrient solution was completely replenished at weekly intervals.

The experiment was a two-factor factorial, the factors being genotypes with two levels, At354 and Pokkali and salt-treatment with eight levels: control $-1 \mathrm{mM} \mathrm{NaCl}$ and seven salt-stress treatments T1- $20 \mathrm{mM} \mathrm{NaCl}, \mathrm{T} 2-40 \mathrm{mM}$ NaCl, T3- 60 mM NaCl, T4- 80 mM NaCl, T5-100 mM $\mathrm{NaCl}, \mathrm{T} 6-120 \mathrm{mM} \mathrm{NaCl}$, and $\mathrm{T} 7-150 \mathrm{mM} \mathrm{NaCl}$. The experiment was laid out in a completely randomized design with four replications. $\mathrm{NaCl}$ was selected for the salt treatment because $\mathrm{NaCl}$ is the most abundant and the most soluble (Flowers, 2004; Munns \& Tester, 2008), out of the different salts that can cause salinity in agricultural lands.

Seeds were imbibed overnight in aerated $1 \% \mathrm{CaSO}_{4}$ solution and wrapped in banana leaves for germination. Pre-germinated seeds were kept between wet filter papers to develop seedlings. After one week, the seedlings were transferred to aerated nutrient solutions in $3 \mathrm{~L}$ plastic containers in a well-ventilated plant house, which was rain-sheltered with a glass roof. Each variety $\mathrm{x}$ salt treatment $\mathrm{x}$ replicate combination was represented with nine plants.

At the time of seedling transfer, the nutrient solution was at $1 / 4$ of full strength. Strength of the nutrient solution was increased in $25 \%$ steps, up to full strength at $2 \mathrm{~d}$ intervals. Salt treatments (control $-1 \mathrm{mM} \mathrm{NaCl}$, stress$20 \mathrm{mM} \mathrm{NaCl}$ ) were started one week after giving the full strength nutrient solution. The control was maintained at $1 \mathrm{mM} \mathrm{NaCl}$ concentration throughout. In salt stress treatments of T2, T3 and T4, salt concentration was increased up to the final concentration in $20 \mathrm{mM}$ steps at $2 \mathrm{~d}$ intervals. In salt stress treatments of T5, T6 and $\mathrm{T} 7$, salt concentration was increased up to $100 \mathrm{mM}$ concentration in $25 \mathrm{mM}$ steps at $2 \mathrm{~d}$ intervals. Two days later, salt concentrations of T6 and T7 were further increased to the respective final concentrations of 120 and $150 \mathrm{mM} \mathrm{Na}^{+}$. Plants were harvested 30 days after commencement of salt treatments, when salt toxicity symptoms appeared in more than $50 \%$ of shoots at the highest salt concentration solution (i.e. $150 \mathrm{mM} \mathrm{NaCl}$ ).

\section{Measurements:}

(a) Plant growth: Leaf growth was quantified by measuring the length and width of the two youngest expanding leaves. Measurements were started $24 \mathrm{~h}$ after imposing stress. Thereafter, leaf growth measurements were taken at $2-7 \mathrm{~d}$ intervals until harvesting. These leaves were selected because their entire duration of expansion occurred during the stress period. When the initially selected leaves completed expanding, measurements were made on the younger expanding leaves. Green leaf area was computed as the product between the respective length and width divided by 2 . At final harvest, the plants were separated into shoots and roots and the fresh and dry weights were measured.

(b) $\mathrm{Na}^{+}$concentration in shoot and root: The two youngest leaves and the roots were taken at the time of harvesting for analysis of tissue $\mathrm{Na}^{+}$concentrations. $\mathrm{Na}^{+}$ ion extraction was done according to the general method for plant samples as described by Van Ranst et al. (1999). $\mathrm{Na}^{+}$ion concentration was measured using a flame photometer.

(c) Visual observations: The time of appearance of visual symptoms of water stress (i.e. leaf rolling) and salt toxicity (i.e. burning of leaf tip and gradual advancement of burning towards the rest of the leaf blade) were recorded.

(d) Data analysis: Data on the measured parameters were analyzed using analysis of variance (ANOVA). Whenever the genotype $\mathrm{x}$ salt concentration interaction effect was found to be significant $(p<0.05)$, significance for salt concentration effects within the genotype was tested by running separate ANOVA for each genotype. Means were separated using either the Least Significant Difference or the Duncan's Multiple Range Test. Responses of selected parameters to increasing salinity were quantified by regression analysis. Appropriate regression models were determined by examining the respective scatter plots. Correlations between different parameters were determined by linear correlation analysis.

The two phases of salt stress development were identified by examining the variation in relative leaf area with time after imposing salt stress. Relative leaf area was calculated as the ratio between area of the youngest expanding leaf at a given salt concentration and that in the control. The point at which relative leaf area shows a significant acceleration in its decline with time was identified as the end of Phase I and the beginning of Phase II of salt stress development. Relative shoot, root and total dry weights were calculated as the ratios between 
the respective mean shoot, root and total dry weights at a given salt concentration and the corresponding mean shoot, root and total dry weights in the control. The respective means of shoot, root and total dry weights were obtained by pooling and averaging the replicate values of each variety $\mathrm{x}$ salt concentration combination.

\section{RESULTS}

\section{Meteorological conditions during the experiment}

Meteorological conditions during the 49 day period of the experiment are presented in Table 1. The respective ranges of variation of all meteorological variables were within the tolerable minimum and maximum thresholds for rice (Yoshida, 1981). Therefore, the meteorological conditions during the experiment did not have any adverse effect on the growth of rice plants.

\section{Total plant biomass and its partitioning}

There was a highly significant $(\mathrm{p}=0.001)$ salinity $\mathrm{x}$ genotype interaction effect on the total plant dry weight $\left(\mathrm{W}_{\mathrm{T}}\right)$, indicating that the genotypes were differentially affected by the different salinity levels. Despite the interaction effect, $\mathrm{W}_{\mathrm{T}}$ at harvest (49 days after transplanting or 30 days after imposition of salt stress) showed highly significant variation between different salinity levels $(\mathrm{p}<0.0001)$ and the two genotypes $(\mathrm{p}<$ 0.0001 ). In the control (i.e. $1 \mathrm{mM} \mathrm{Na}^{+}$), the two varieties did not show a significant difference in their $\mathrm{W}_{\mathrm{T}}$ (Figure 1a). When salinity was increased from $1 \mathrm{mM} \mathrm{Na}^{+}$, both genotypes showed significant linear decreases in $\mathrm{W}_{\mathrm{T}}$ until the salinity level increased up to a threshold value. $\mathrm{W}_{\mathrm{T}}$ of At354 decreased at a rate of $16.6 \pm 2.6 \mathrm{mg} \mathrm{mM}^{-1}$

Table 1: Meteorological conditions during the 49 day period of the experiment.

\begin{tabular}{lccc}
\hline \multicolumn{1}{c}{ Variable } & Maximum & Minimum & Mean \\
\hline $\begin{array}{l}\text { Daily maximum air } \\
\text { temperature }\left({ }^{\circ} \mathrm{C}\right)\end{array}$ & 32.7 & 25.5 & 29.60 \\
$\begin{array}{l}\text { Daily minimum air } \\
\text { temperature }\left({ }^{\circ} \mathrm{C}\right)\end{array}$ & 24.6 & 21.0 & 22.50 \\
$\begin{array}{l}\text { Daily mean air } \\
\text { temperature }\left({ }^{\circ} \mathrm{C}\right)\end{array}$ & 27.7 & 23.5 & 26.10 \\
$\begin{array}{l}\text { Daily mean relative } \\
\text { humidity }(\%)\end{array}$ & 92.0 & 32.0 & 76.30 \\
$\begin{array}{l}\text { Daily sunshine } \\
\text { duration }\left(\mathrm{h} \mathrm{d}^{-1}\right)\end{array}$ & 11.2 & 0.1 & 05.23 \\
$\begin{array}{l}\text { Pan evaporation rate } \\
\left(\mathrm{mm} \mathrm{d}^{-1}\right)\end{array}$ & 7.5 & 0.1 & 02.89 \\
\hline
\end{tabular}

$\mathrm{Na}^{+}\left(\mathrm{R}^{2}=0.58\right)$ when the salinity level increased from 1 to $80 \mathrm{mM} \mathrm{Na}^{+}$. This was followed by a faster rate of decrease of $37.7 \mathrm{mg} \mathrm{mM}^{-1} \mathrm{Na}^{+}$, when the salinity increased from 80 to $100 \mathrm{mM} \mathrm{Na}^{+}$. $\mathrm{W}_{\mathrm{T}}$ of At354 did not decrease significantly below the minimum that was reached at 100 $\mathrm{mM} \mathrm{Na}$, even when the salinity level increased beyond $100 \mathrm{mM} \mathrm{Na}^{+}$up to $150 \mathrm{mM} \mathrm{Na}$. As compared to At354, Pokkali showed a faster rate of decrease in $\mathrm{W}_{\mathrm{T}}(34.2 \pm 5.6$ $\mathrm{mg} \mathrm{mM} \mathrm{ma}^{-1} \mathrm{Na}^{+}, \mathrm{R}^{2}=0.62$ ), when salinity increased from 1 to $60 \mathrm{mM} \mathrm{Na}^{+}$(Figure 1a). Although $\mathrm{W}_{\mathrm{T}}$ continued to show a very slow decline when salinity increased beyond $60 \mathrm{mM} \mathrm{Na}^{+}$, the $\mathrm{W}_{\mathrm{T}}$ values were not significantly $(p=0.05)$ different. At a given level of salinity, At354 always showed a higher $\mathrm{W}_{\mathrm{T}}$ than Pokkali (Figure 1a). This varietal difference was significant $(\mathrm{p}<0.05)$ at all levels of salinity, except at 20 and $100 \mathrm{mM} \mathrm{Na}{ }^{+}$. Relative $\mathrm{W}_{\mathrm{T}}$ (i.e. $\mathrm{W}_{\mathrm{T}}$ at a given level of salinity as a ratio of that in the respective control) (Figure 1b) also showed a variation pattern that was very similar to that of $\mathrm{W}_{\mathrm{T}}$.
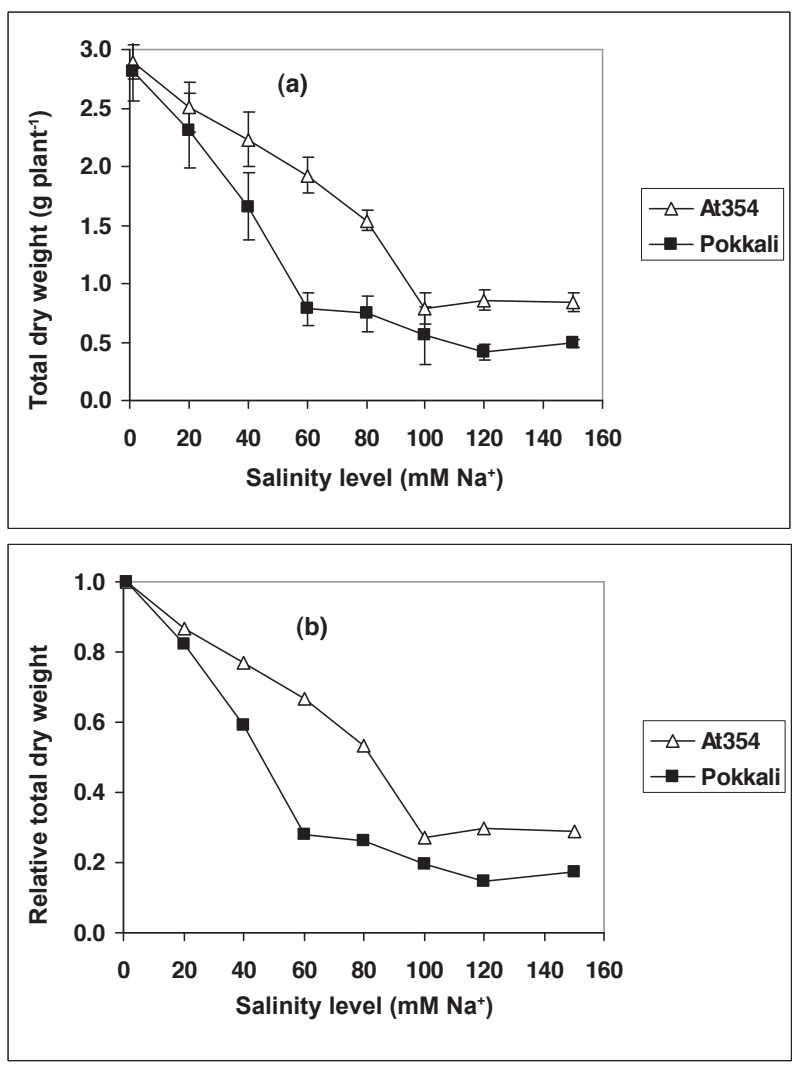

Figure 1: Response of: (a) total plant dry weight and (b) relative total plant dry weight (i.e. total plant dry weight at a given level of salinity as a ratio of the control) of At354 and Pokkali to increasing level of salinity. All measurements were taken 30 days after imposing salinity. Vertical error bars indicate $95 \%$ confidence intervals. 
Table 2: Linear correlation coefficients among total shoot and root dry weights and shootweight ratio.

\begin{tabular}{lllll}
\hline & $\begin{array}{l}\text { Total plant dry } \\
\text { weight }\end{array}$ & $\begin{array}{l}\text { Shoot dry } \\
\text { weight }\end{array}$ & $\begin{array}{l}\text { Root dry } \\
\text { weight }\end{array}$ & $\begin{array}{l}\text { Shoot-weight } \\
\text { ratio }\end{array}$ \\
\hline $\begin{array}{l}\text { Total plant dry } \\
\text { weight }\end{array}$ & - & 0.998 & 0.989 & -0.783 \\
Shoot dry & $(\mathrm{p}<0.0001)$ & $(\mathrm{p}<0.0001)$ & $(\mathrm{p}=0.0003)$ \\
weight & - & 0.979 & -0.760 \\
Root dry & & $(\mathrm{p}<0.0001)$ & $(\mathrm{p}=0.0006)$ \\
weight & & & -0.829 \\
\hline
\end{tabular}

Note: Data from both genotypes and all salinity treatments were pooled

The respective shoot dry weights $\left(\mathrm{W}_{\mathrm{sh}}\right)$ and root dry weights $\left(\mathrm{W}_{\mathrm{rt}}\right)$ showed highly significant correlations with $\mathrm{W}_{\mathrm{T}}$ (Table 2). On the other hand, the shoot-weight ratio (i.e. ratio between $\mathrm{W}_{\mathrm{sh}}$ and $\mathrm{W}_{\mathrm{T}}$ ) showed highly significant negative correlations with $\mathrm{W}_{\mathrm{T}}, \mathrm{W}_{\mathrm{sh}}$ and $\mathrm{W}_{\mathrm{rt}}$.

\section{Shoot $\mathrm{Na}^{+}$concentration $\left(\mathrm{Na}_{\mathrm{sh}}\right)$}

The genotype $\mathrm{x}$ salt concentration interaction effect on shoot $\mathrm{Na}^{+}$concentration $\left(\mathrm{Na}_{\mathrm{sh}}\right)$ was found to be highly significant $(\mathrm{p}=0.001)$. Despite the interaction effect, $\mathrm{Na}_{\text {sh }}$ showed highly significant variation with salinity level $(\mathrm{p}<0.0001)$ and genotypes $(\mathrm{p}=0.01)$. In both varieties, there was a continuous increase of $\mathrm{Na}_{\mathrm{sh}}$ with increasing salt concentration in the external medium (Figure 2a). Analysis of variance of $\mathrm{Na}_{\mathrm{sh}}$ for different external $\mathrm{Na}^{+}$concentrations showed that in both varieties, $\mathrm{Na}_{\text {sh }}$ of salinized treatments did not differ significantly $(p<0.05)$ from that of the control (i.e. $1 \mathrm{mM} \mathrm{Na}^{+}$) until salinity exceeded $40 \mathrm{mM} \mathrm{Na}^{+}$. Within the range between 40 and $80 \mathrm{mM} \mathrm{Na}^{+}, \mathrm{Na}_{\mathrm{sh}}$ in both genotypes showed a gradual increase. Both genotypes showed substantial increases of $\mathrm{Na}_{\mathrm{sh}}$ when the salinity level increased beyond $80 \mathrm{mM} \mathrm{Na}^{+}$, with Pokkali showing a greater rate of increase [i.e. $26.1 \mathrm{mM} \mathrm{Na}^{+} \mathrm{kg}^{-1}\left(\mathrm{mM} \mathrm{Na}^{+}\right)^{-1}$ with linear $\left.\mathrm{R}^{2}=0.77\right]$ than At354 $\left[18.3 \mathrm{mM} \mathrm{Na} \mathrm{kg}^{-1}(\mathrm{mM}\right.$ $\left.\mathrm{Na}^{+}\right)^{-1}$ with linear $\mathrm{R}^{2}=0.73$ ]. Pokkali had a significantly $(\mathrm{p}<0.05)$ greater $\mathrm{Na}_{\mathrm{sh}}$ than At354 at all external $\mathrm{Na}^{+}$ concentrations beyond $80 \mathrm{mM} \mathrm{Na}^{+}$.

\section{$\operatorname{Root} \mathrm{Na}^{+}$concentration $\left(\mathrm{Na}_{\mathrm{rt}}\right)$}

With respect to root $\mathrm{Na}^{+}$concentration $\left(\mathrm{Na}_{\mathrm{rt}}\right)$, the genotype $\mathrm{x}$ salt concentration interaction effect was found to be not significant at $\mathrm{p}=0.05$. However, $\mathrm{Na}_{\mathrm{rt}}$ showed highly significant variation between salt concentrations in the external medium $(\mathrm{p}<0.0001)$ and genotypes $(\mathrm{p}<0.0001)$. Both genotypes showed an increasing overall trend in their respective $\mathrm{Na}_{\mathrm{rt}}$ (Figure 2b) with At354 showing a greater rate of increase [i.e. $10.3 \mathrm{mM} \mathrm{Na} \mathrm{kg}^{-1}(\mathrm{mM}$ $\left.\mathrm{Na}^{+}\right)^{-1}$ with linear $\left.\mathrm{R}^{2}=0.74\right]$ as compared to Pokkali [8.3 $\mathrm{mM} \mathrm{Na}^{+} \mathrm{kg}^{-1}\left(\mathrm{mM} \mathrm{Na}^{+}\right)^{-1}$ with linear $\left.\mathrm{R}^{2}=0.66\right]$ across the whole range of external salt concentrations. In contrast to $\mathrm{Na}_{\mathrm{sh}}, \mathrm{Na}_{\mathrm{rt}}$ was significantly $(\mathrm{p}<0.05)$ greater in At354 than in Pokkali at all levels of salinity except 20 and 120 $\mathrm{mM} \mathrm{Na}^{+}$.
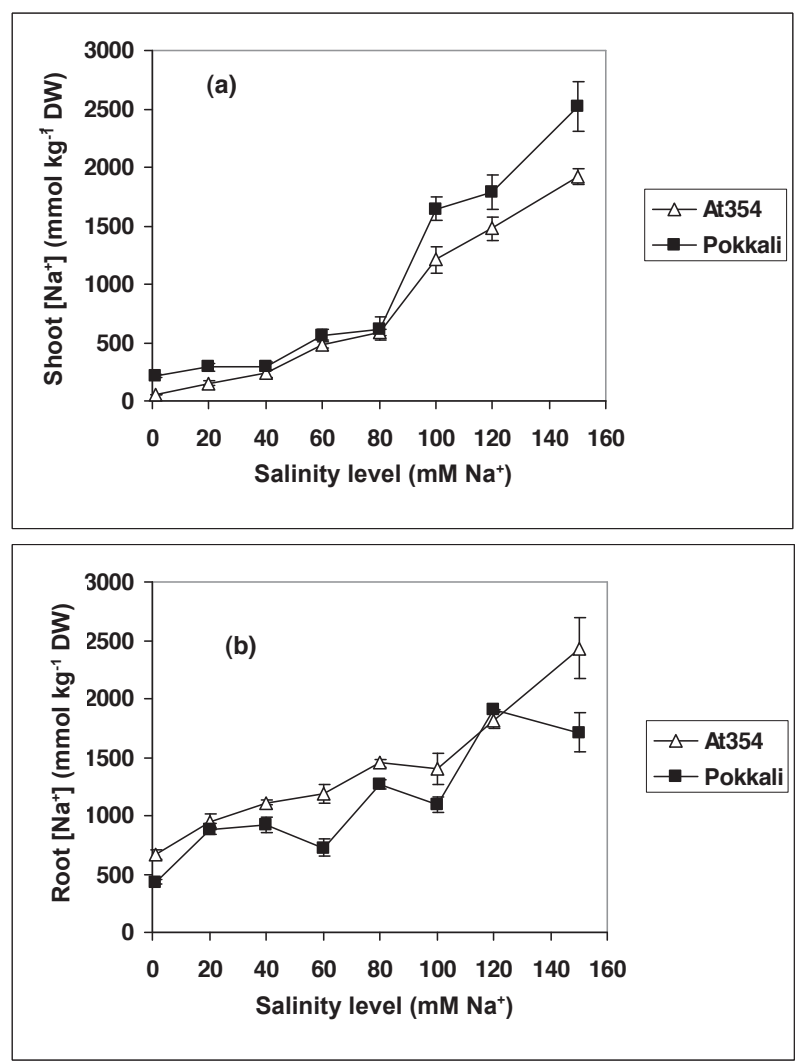

Figure 2: Response of shoot (a) and root (b) $\mathrm{Na}^{+}$concentrations of At354 and Pokkali to increasing level of salinity. All measurements were taken 30 days after imposing salinity. Vertical error bars indicate $95 \%$ confidence intervals. 


\section{Shoot:root $\mathrm{Na}^{+}$concentration ratio $\left(\mathrm{R}_{\mathrm{Na}}\right)$}

The genotype $\mathrm{x}$ salt concentration interaction effect on the ratio between shoot and root $\mathrm{Na}^{+}$concentrations $\left(\mathrm{R}_{\mathrm{Na}}\right)$ was found to be highly significant $(\mathrm{p}=0.0007)$. Despite the interaction effect, $\mathrm{R}_{\mathrm{Na}}$ showed highly $(\mathrm{p}<0.0001)$ significant variation between salinity levels and genotypes. Despite unexpected fluctuations, which were probably due to the fluctuations of $\mathrm{Na}_{\mathrm{rt}}, \mathrm{R}_{\mathrm{Na}}$ for both varieties showed an overall increasing trend across the whole range of external salt concentrations (Figure 3). Here, Pokkali showed a higher linear rate of increase in $\mathrm{R}_{\mathrm{Na}}$ [i.e. $0.0077\left(\mathrm{mM} \mathrm{Na}^{+}\right)^{-1}$ with linear $\mathrm{R}^{2}=0.60$ ] than that of At354 [0.0062 $\left(\mathrm{mM} \mathrm{Na}^{+}\right)^{-1}$ with linear $\left.\mathrm{R}^{2}=0.56\right]$. Pokkali had a significantly $(\mathrm{p}<0.05)$ greater $\mathrm{R}_{\mathrm{Na}}$ than At354 at all levels of salinity except at 80 and $120 \mathrm{mM}$ $\mathrm{Na}^{+}$.

Relationship between relative shoot and root growth and the respective tissue $\mathrm{Na}^{+}$concentrations under salt stress

A negative significant power function adequately described the relationship between tissue $\mathrm{Na}^{+}$ concentration and relative dry weight for both shoot (Figure 4a) and root (Figure 4b). Coefficients of the power functions clearly showed that relative shoot growth of Pokkali was more sensitive to increasing $\mathrm{Na}_{\text {sh }}$ than that of At354. However, no clear genotypic difference was found in the sensitivity of relative root growth to increasing $\mathrm{N}_{\mathrm{rt}}$. Because shoot dry weight formed the major portion of the total plant dry weight, the relationship between relative total plant dry weight and $\mathrm{Na}_{\text {sh }}$ could also be described adequately by a negative power function (Figure 5),

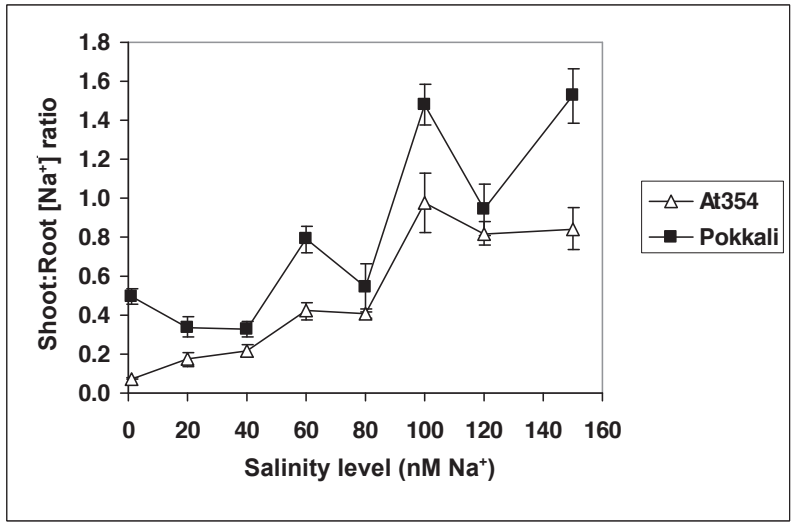

Figure 3: Response of shoot: root $\mathrm{Na}^{+}$concentration ratio of At354 and Pokkali to increasing level of salinity. All measurements were taken 30 days after imposing salinity. Vertical error bars indicate $95 \%$ confidence intervals. which had similar $\mathrm{R}^{2}$ values to that of the corresponding relationship between relative shoot dry weight and $\mathrm{Na}_{\mathrm{sh}}$ (Figure 4a).

\section{Variation of relative leaf area with time at different $\mathrm{Na}^{+}$concentrations}

In both genotypes, relative green leaf area $\left(\mathrm{RL}_{\mathrm{A}}\right)$ did not show a significant decline at $20 \mathrm{mM} \mathrm{Na}^{+}$even 27 days after imposition of salt stress (Figure 6a). At 40, 60 and $80 \mathrm{mM} \mathrm{Na}^{+}, \mathrm{RL}_{\mathrm{A}}$ showed significant reductions with time (Figures $6 \mathrm{~b}-\mathrm{d} \&$ Table 3 ). The respective rates of reduction increased with increasing levels of salinity (Table 3 ). However, in both genotypes, the rates of reduction of $\mathrm{RL}_{\mathrm{A}}$ with time were uniform
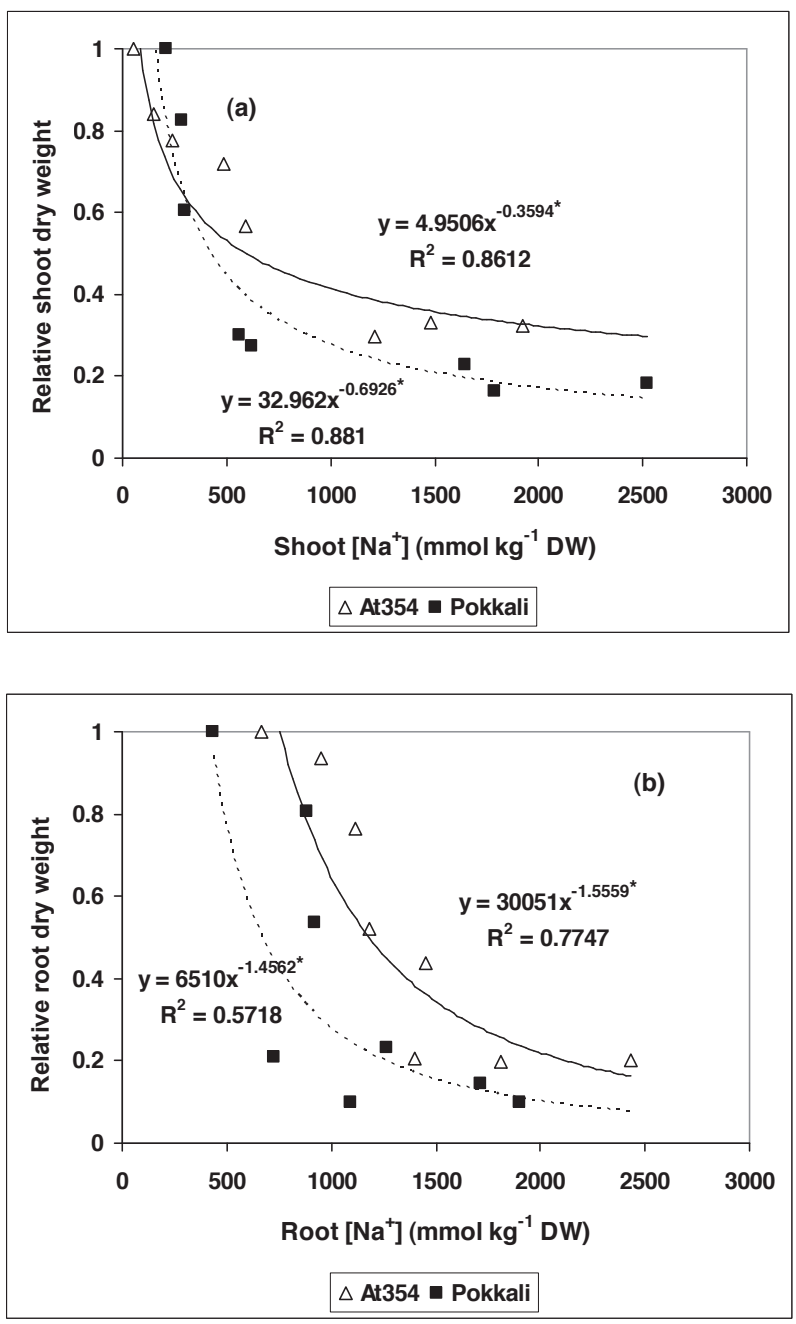

Figure 4: Relationships between relative shoot (a) and root (b) growth and their respective $\mathrm{Na}^{+}$concentrations of At354 and Pokkali at 30 days after imposing salt stress.

* - Coefficient is significantly different from zero at $\mathrm{p}<0.05$ 


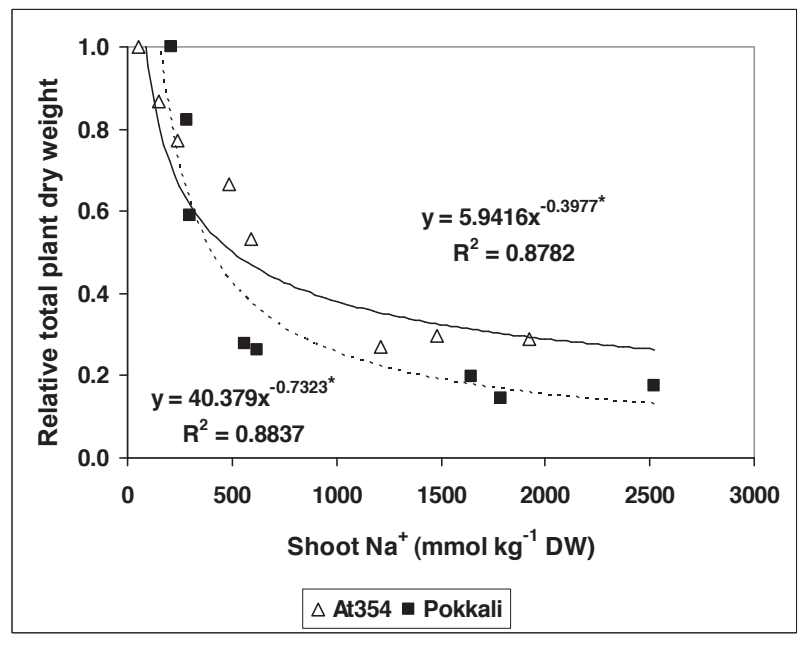

Figure 5: Relationships between relative total plant dry weight and shoot $\mathrm{Na}^{+}$concentration of At354 and Pokkali at 30 days after imposing salt stress.

* - Coefficient is significantly different from zero at $\mathrm{p}<0.05$ throughout the period of observation, as indicated by the very high (i.e. $>0.95) \mathrm{R}^{2}$ values for the fitted linear regressions. Therefore, identification of the two phases of salt stress development was not possible. In contrast, the two phases could be identified clearly at $100 \mathrm{mM} \mathrm{Na}^{+}$(Figure 6e), with the first phase (i.e. from 0 to 10 days after reaching $100 \mathrm{mM} \mathrm{Na}$ ) showing a significantly lower rate of reduction of $\mathrm{RL}_{\mathrm{A}}$ than the second phase (i.e. after 10 days). Notably, the rates of reduction during the identified second phase at $100 \mathrm{mM}$ $\mathrm{Na}^{+}$were substantially greater than the uniform rates observed at 40, 60 and $80 \mathrm{mM} \mathrm{Na}^{+}$(Table 3).

At salinity levels greater than $100 \mathrm{mM} \mathrm{Na}^{+}$(i.e. 120 and $150 \mathrm{mM} \mathrm{Na}^{+}$), the phase of rapid reduction of $\mathrm{RL}_{\mathrm{A}}$ had already started in Pokkali, when the target salinity level was reached (Figures $6 f \& \mathrm{~g}$ ). At these two high salinity treatments, the phase of rapid $\mathrm{RL}_{\mathrm{A}}$ reduction was followed by a phase of comparatively slower reduction (Table 3). By this time, the plants were showing clear symptoms of salt toxicity and their rate of growth had reduced substantially.

Table 3: Rate of reduction of relative leaf area with time after reaching the target salinity level at different levels of salinity in At354 and Pokkali.

\begin{tabular}{|c|c|c|c|c|c|}
\hline $\begin{array}{c}\text { Salinity } \\
\text { level } \\
(\mathrm{mM} \\
\left.\mathrm{Na}^{+}\right)\end{array}$ & $\begin{array}{c}\text { Period } \\
\text { considered } \\
\text { (days after } \\
\text { reaching } \\
\text { salinity level) }\end{array}$ & $\begin{array}{l}\text { At354 } \\
\text { rate of } \\
\text { reduction of } \\
\text { relative leaf } \\
\text { area }\left(\mathrm{d}^{-1}\right)\end{array}$ & $\mathrm{R}^{2}$ & $\begin{array}{l}\text { Pokkali } \\
\text { rate of } \\
\text { reduction of } \\
\text { relative leaf } \\
\text { area }\left(\mathrm{d}^{-1}\right)\end{array}$ & $\mathrm{R}^{2}$ \\
\hline 40 & $0-20$ & $0.041 * * *$ & 0.97 & $0.027 * * *$ & 0.98 \\
\hline 60 & $0-17$ & $0.065^{* * *}$ & 0.99 & $0.036^{* * *}$ & 0.99 \\
\hline 80 & $0-19$ & $0.111 * * *$ & 0.97 & $0.056 * * *$ & 0.99 \\
\hline \multirow[t]{3}{*}{100} & $0-10$ & $0.016^{* * *}$ & 0.89 & $0.032 * * *$ & 0.98 \\
\hline & $10-13$ & 0.346 & n.a. & 0.283 & n.a. \\
\hline & $10-18$ & $0.139 * *$ & 0.74 & $0.122 * *$ & 0.78 \\
\hline \multirow[t]{2}{*}{120} & $0-3$ & $0.265 * * *$ & 0.90 & $0.175^{* * *}$ & 0.99 \\
\hline & $3-15$ & $0.083 * * *$ & 0.92 & $0.033 * * *$ & 0.96 \\
\hline \multirow[t]{3}{*}{150} & $0-3$ & $0.391 * * *$ & 0.99 & $0.284 * * *$ & 0.98 \\
\hline & $3-10$ & 0.087 & n.a. & 0.051 & n.a. \\
\hline & $3-15$ & $0.066 * * *$ & 0.95 & $0.031 * *$ & 0.83 \\
\hline
\end{tabular}

n.a. - $\mathrm{R}^{2}$ value is not available as only two data points were used to calculate the rate of reduction.

** - Regression coefficient is significantly different from zero at $\mathrm{p}<0.01$

$* * *$ - Regression coefficient is significantly different from zero at $\mathrm{p}<0.0001$ 
Except at $20 \mathrm{mM} \mathrm{Na}$, the $\mathrm{RL}_{\mathrm{A}}$ values of At354 were greater than the respective values of Pokkali (Figure 6).
However, the rates of reduction of $\mathrm{RL}_{\mathrm{A}}$ with time were greater in At354 as compared to Pokkali (Table 3).
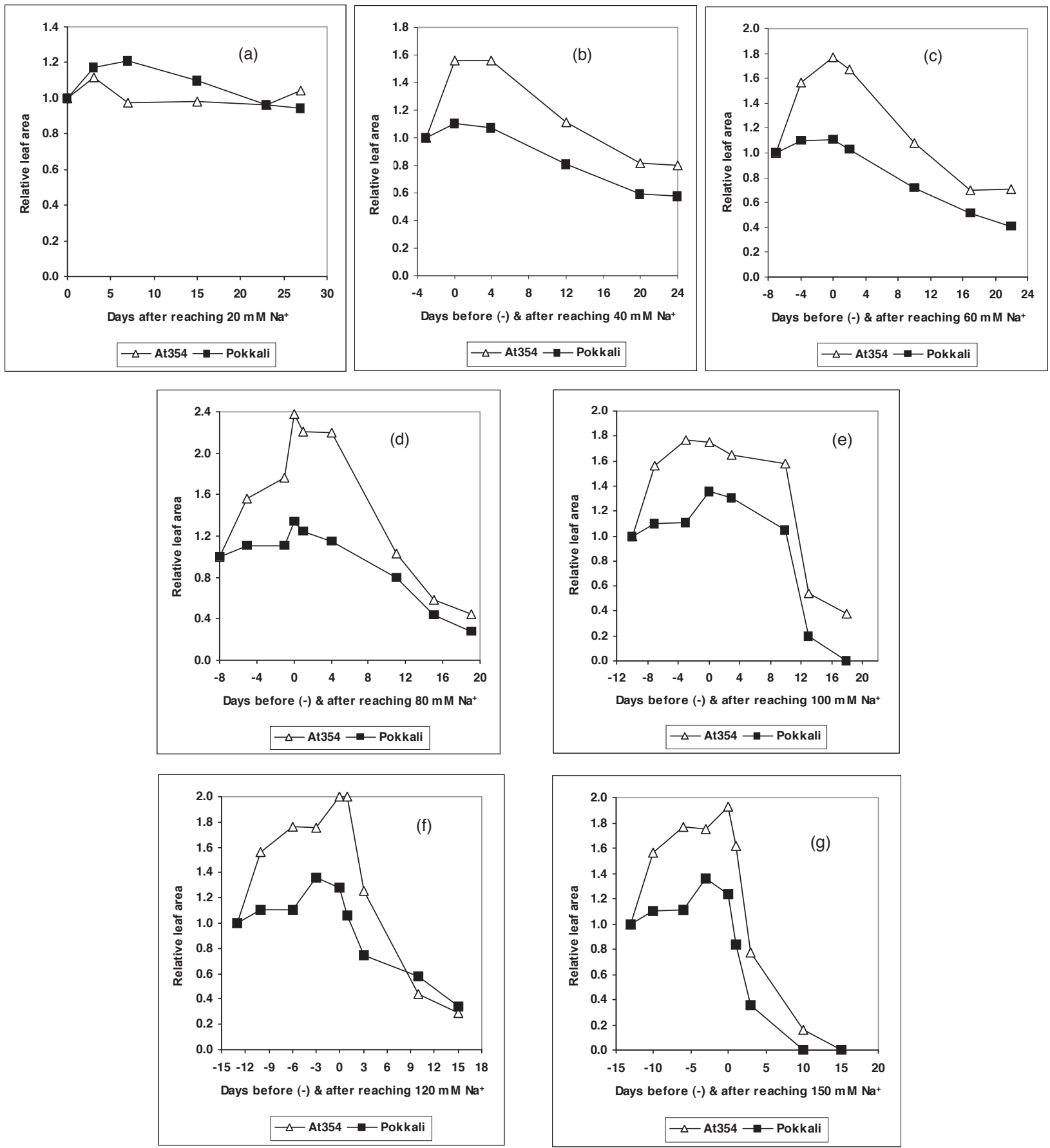

Figure 6: Variation of relative green leaf area of At 354 and Pokkali with time, after reaching the respective target salinity levels: (a) 20 ; (b) 40 ; (c) 60 ; (d) 80 ; (e) 100 ; (f) 120 and (g) $150 \mathrm{mM} \mathrm{Na}^{+}$. Except the $20 \mathrm{mM} \mathrm{Na}^{+}$treatment, all other target salinity levels were achieved as step-wise increases (see Methods and Materials for more details). The measurements started from the first step of salt stress imposition. All measurements were standardized to the initial values at the time of salt stress imposition. 
Table 4: Visual observations on the response of At354 and Pokkali to different levels of salt stress: Time of transition from Phase I to Phase II and appearance of water stress and salt toxicity symptoms.

\begin{tabular}{|c|c|c|c|c|}
\hline $\begin{array}{l}\text { Salt stress } \\
\text { level (mM } \\
\mathrm{NaCl})\end{array}$ & Variety & $\begin{array}{l}\text { Point of significant } \\
\text { acceleration in the } \\
\text { decline of relative } \\
\text { leaf area }^{1}\end{array}$ & $\begin{array}{l}\text { Point at which water } \\
\text { stress symptoms } \\
\text { first appeared (DAT) }\end{array}$ & $\begin{array}{l}\text { Point at which salt toxicity } \\
\text { symptoms first appeared } \\
\text { (DAT) }\end{array}$ \\
\hline \multirow[t]{2}{*}{$20 \mathrm{mM}$} & At354 & $\begin{array}{l}\text { Did not observe } \\
\text { even after } 27 \text { DAT }\end{array}$ & $\begin{array}{l}\text { Did not observe even } \\
\text { after } 27 \text { DAT }\end{array}$ & $\begin{array}{l}\text { Did not observe even after } \\
27 \text { DAT }\end{array}$ \\
\hline & Pokkali & $\begin{array}{l}\text { Did not observe even } \\
\text { after } 27 \text { DAT }\end{array}$ & $\begin{array}{l}\text { Did not observe even } \\
\text { after } 27 \text { DAT }\end{array}$ & $\begin{array}{l}\text { Did not observe even } \\
\text { after } 27 \text { DAT }\end{array}$ \\
\hline \multirow[t]{2}{*}{$40 \mathrm{mM}$} & At354 & $\begin{array}{l}\text { Did not observe even } \\
\text { after } 24 \text { DAT }\end{array}$ & $\begin{array}{l}\text { Did not observe even } \\
\text { after } 27 \text { DAT }\end{array}$ & $\begin{array}{l}\text { Burning of leaf tip at } \\
24 \text { DAT }\end{array}$ \\
\hline & Pokkali & $\begin{array}{l}\text { Did not observe even } \\
\text { after } 24 \text { DAT }\end{array}$ & $\begin{array}{l}\text { Did not observe even } \\
\text { after } 27 \text { DAT }\end{array}$ & $\begin{array}{l}\text { Burning of leaf tip at } \\
20 \text { DAT }\end{array}$ \\
\hline \multirow[t]{2}{*}{$60 \mathrm{mM}$} & At354 & $\begin{array}{l}\text { Did not observe even } \\
\text { after } 22 \text { DAT }\end{array}$ & $\begin{array}{l}\text { Did not observe even } \\
\text { after } 27 \text { DAT }\end{array}$ & $\begin{array}{l}\text { Burning of leaf tip at } \\
15 \text { DAT }\end{array}$ \\
\hline & Pokkali & $\begin{array}{l}\text { Did not observe even } \\
\text { after } 22 \text { DAT }\end{array}$ & $\begin{array}{l}\text { Leaf rolling on the } \\
\text { same day of increasing } \\
\text { salinity up to } 60 \mathrm{mM} \\
\mathrm{NaCl}\end{array}$ & $\begin{array}{l}\text { Burning of leaf } \\
\text { tip at } 12 \text { DAT }\end{array}$ \\
\hline \multirow[t]{2}{*}{$80 \mathrm{mM}$} & At354 & $\begin{array}{l}\text { Did not observe even } \\
\text { after } 19 \text { DAT }\end{array}$ & $\begin{array}{l}\text { Slight leaf rolling on } \\
\text { the same day of } \\
\text { increasing salinity } \\
\text { up to } 80 \mathrm{mM} \mathrm{NaCl}\end{array}$ & $\begin{array}{l}\text { Burning of leaf tip at } \\
4 \text { DAT } \\
\text { Leaf scorching at } 9 \text { DAT }\end{array}$ \\
\hline & Pokkali & $\begin{array}{l}\text { Did not observe } \\
\text { even after } 19 \text { DAT }\end{array}$ & $\begin{array}{l}\text { Leaf rolling to a greater } \\
\text { extent than that in } \\
\text { At } 354 \text { on the same day } \\
\text { of increasing salinity } \\
\text { up to } 80 \mathrm{mM} \mathrm{NaCl}\end{array}$ & $\begin{array}{l}\text { Burning of leaf tip at } \\
4 \text { DAT } \\
\text { Leaf scorching at } 9 \text { DAT } \\
\text { (Both symptoms to a } \\
\text { greater extent than At354) }\end{array}$ \\
\hline \multirow[t]{2}{*}{$100 \mathrm{mM}$} & At354 & $10 \mathrm{DAT}$ & $\begin{array}{l}\text { Slight leaf rolling at } \\
2 \text { DAT }\end{array}$ & $\begin{array}{l}\text { Slight burning of leaf tip } \\
\text { at } 2 \text { DAT } \\
\text { Leaf scorching at } 7 \text { DAT }\end{array}$ \\
\hline & Pokkali & 10 DAT & $\begin{array}{l}\text { Wilting of all leaves at } \\
1 \text { DAT }\end{array}$ & $\begin{array}{l}\text { Clear burning of leaf tip } \\
\text { at } 2 \text { DAT } \\
\text { Leaf scorching at } 5 \text { DAT }\end{array}$ \\
\hline \multirow[t]{2}{*}{$120 \mathrm{mM}$} & At354 & $\begin{array}{l}\text { Rapid decline } \\
\text { started at the point } \\
\text { of reaching the } \\
\text { target salinity level } \\
\text { (i.e. } 0 \text { DAT) }\end{array}$ & $\begin{array}{l}\text { Leaf rolling before } \\
\text { salinity was increased } \\
\text { up to } 120 \mathrm{mM} \\
\text { Leaf wilting at } 1 \text { DAT } \\
\text { (i.e. one day after } \\
\text { salinity reached } 120 \mathrm{mM} \text { ) } \\
\text { Intensity of symptoms } \\
\text { were less than in } \\
\text { Pokkali }\end{array}$ & $\begin{array}{l}\text { Tip burn before salinity } \\
\text { was increased up to } \\
120 \mathrm{mM} \\
\text { Leaf scorching at } 3 \text { DAT }\end{array}$ \\
\hline & Pokkali & $\begin{array}{l}\text { Rapid decline } \\
\text { started at the point } \\
\text { of reaching the } \\
\text { target salinity level } \\
\text { (i.e. } 0 \text { DAT) }\end{array}$ & $\begin{array}{l}\text { Leaf rolling before } \\
\text { salinity was increased } \\
\text { up to } 120 \mathrm{mM} \\
\text { Leaf wilting at } 1 \text { DAT } \\
\text { (i.e. one day after salinity } \\
\text { reached } 120 \mathrm{mM} \text { ) }\end{array}$ & $\begin{array}{l}\text { Tip burn before salinity } \\
\text { was increased up to } \\
120 \mathrm{mM} \\
\text { Leaf scorching at } 2 \text { DAT }\end{array}$ \\
\hline
\end{tabular}

- continued 


\begin{tabular}{|c|c|c|c|c|}
\hline $\begin{array}{l}\text { Salt stress } \\
\text { level }(\mathrm{mM} \\
\mathrm{NaCl})\end{array}$ & Variety & $\begin{array}{l}\text { Point of significant } \\
\text { acceleration in the } \\
\text { decline of relative } \\
\text { leaf area }\end{array}$ & $\begin{array}{l}\text { Point at which water } \\
\text { stress symptoms } \\
\text { first appeared (DAT) }\end{array}$ & $\begin{array}{l}\text { Point at which salt toxicity } \\
\text { symptoms first appeared } \\
\text { (DAT) }\end{array}$ \\
\hline \multirow[t]{2}{*}{$150 \mathrm{mM}$} & At354 & $\begin{array}{l}\text { Rapid decline } \\
\text { started at the point } \\
\text { of reaching the } \\
\text { target salinity level } \\
\text { (i.e. } 0 \text { DAT) }\end{array}$ & $\begin{array}{l}\text { Leaf rolling and wilting } \\
\text { before salinity was } \\
\text { increased up to } \\
150 \mathrm{mM}\end{array}$ & $\begin{array}{l}\text { Tip burn and leaf scorching } \\
\text { before salinity was increased } \\
\text { up to } 150 \mathrm{mM}\end{array}$ \\
\hline & Pokkali & $\begin{array}{l}\text { Rapid decline } \\
\text { started at the point } \\
\text { of reaching the } \\
\text { target salinity level } \\
\text { (i.e. } 0 \text { DAT) }\end{array}$ & $\begin{array}{l}\text { Leaf rolling and wilting } \\
\text { before salinity was } \\
\text { increased up to } \\
150 \mathrm{mM}\end{array}$ & $\begin{array}{l}\text { Tip burn and leaf scorching } \\
\text { before salinity was } \\
\text { increased up to } 150 \mathrm{mM}\end{array}$ \\
\hline
\end{tabular}

\footnotetext{
1 - Based on Figure 6

DAT - Days after reaching target salinity
}

\section{Visual observations of water stress and salt toxicity}

Visual symptoms of water stress (i.e. leaf rolling) and salt toxicity (i.e. burning of leaf tip and gradual advancement of burning towards the rest of the leaf blade) appeared (Table 4) before the point of commencement of rapid decline in $\mathrm{RL}_{\mathrm{A}}$. Both water stress and salt toxicity symptoms appeared slightly earlier in Pokkali as compared to At354.

\section{DISCUSSION}

Comparison and validation of the screening method developed with other methods of screening for salt tolerance

The ultimate measure of salt tolerance of a given crop variety would be its ability to produce a high yield in a naturally saline environment. However, there are several practical difficulties in using the above criterion for screening of a large number of genotypes/accessions/ varieties. Firstly, the plants need to be grown in the saline environment for a lengthy period of time (i.e. 3 months or more in the case of rice) until they produce a yield. During this lengthy period, in a natural environment, the salinity level can fluctuate due to several factors such as rainfall and drainage conditions in the field. Secondly, screening a large number of genotypes in the field requires a considerable land area, within which the level of salinity is often non-uniformly distributed (Richards, 1983) due to spatial heterogeneity of soil chemical and physical factors that are responsible for salinity. As a result, different genotypes may be growing under different levels of salinity, thus making valid comparisons difficult. Thirdly, screening and identification of genotypes of relative salt tolerance based on their final yield will not provide information on the different physiological, metabolic, growth and phenological traits that may have contributed to produce a higher yield under salinity. It is highly likely that salt tolerance is polygenic and is controlled by a large number of genes or groups of genes (Flowers \& Yeo, 1995; Munns, 2005; Munns \& Tester, 2008). Therefore, a varietal screening method should not only identify genotypes of relatively greater tolerance but also provide indications of the physiological basis of the observed salt tolerance.

The screening method developed and tested in the present study did not have the above-mentioned disadvantages. Firstly, it provided a measure of salt tolerance (i.e. relative leaf area) within a shorter time period. At the optimum salinity level of $100 \mathrm{mM} \mathrm{Na}^{+}$, the whole screening process took less than 20 days after imposition of salt stress (Figure 6e). Taking into account the time that was required for raising the seedlings, transferring and acclimatization in the nutrient solutions and step-wise imposition of the target level of salt-stress, the whole period of screening took less than 50 days. This is a considerable reduction of the time required to complete one round of screening in comparison to screening based on yield, which takes longer than 3 months based on the life cycle duration of the genotypes being screened. Secondly, by growing plants in nutrient solutions, all genotypes that are being screened could be subjected to uniform and constant levels of salt stress unlike in the field where the salinity levels vary, both 
spatially and temporally. Thirdly, by allowing separation of the two physiological phases of responses to salt stress, the present method provides indications of the physiological basis of salt tolerance, which could be further explored through molecular and biochemical studies.

Abeysiriwardena (2004) proposed a rapid screening technique based on germination percentage after soaking the seeds in a solution of high salinity (i.e. 45 $\mathrm{dS} \mathrm{m} \mathrm{m}^{-1}$, which is equivalent to $450 \mathrm{mM} \mathrm{Na}^{+}$) for 9 days. Screening of 10 rice varieties of known salt tolerance in the field, including Pokkali and Nona Bokra using the above method, has shown that the ability to sustain seed viability under high salt concentration as measured by post-soaking germination percentage had a positive correlation with the level of salt tolerance shown in the field. Sirisena and Abeysiriwardena (2005); Dissanayake and Wijeratne (2006) and Subasinghe et al. (2007) also used the same method to screen the salt tolerance of 10 and 28 Sri Lankan rice, varieties, respectively and obtained similar results. However, Munns and James (2003) concluded that screening based on germination at high salinity did not discriminate between genotypes of varying salt tolerance at moderate levels of salinity (i.e. $50-100 \mathrm{mM} \mathrm{NaCl}$ ), which are typical of the salinity levels encountered under actual field conditions. Consequently, there has been poor correlation between varietal classifications of salt tolerance based on germination and those based on actual field performance (Munns \& James, 2003). This is understandable as the processes that are responsible for cell expansion during germination (i.e. water uptake and swelling) are different from the processes responsible for seedling growth (i.e. cell division and expansion and photosynthesis).

Identification of the two phases of salt stress development, the point of transfer from Phase I to Phase II and determination of the optimum level of salinity for varietal screening

The primary objective of the present study was to determine an optimum level of salinity for rapid screening of a large number of rice genotypes/accessions/varieties hydroponically for salt-tolerance during the two phases of salt stress development. Time courses of variation of relative area of the two youngest expanding leaves at each salinity level were used to identify the two phases of salt stress development. Leaf growth was used for this purpose because of two reasons. Firstly, leaf expansion is a process, which is more sensitive to water and salt stress than total dry weight (Munns, 2002; De Costa et al., 2007). Secondly, leaf growth can be measured nondestructively while total dry weight needs a destructive measurement. Rawson et al. (1988) concluded that leaf area expansion rates of several cereal genotypes under salinity correlated with biomass production rates, which in turn showed adequate correlation with salt tolerance based on grain yield.

Based on the results of the present study, $100 \mathrm{mM}$ $\mathrm{Na}^{+}$was identified as the optimum salinity level for varietal screening of rice germplasm, under hydroponic conditions, for identification of salt tolerance during the two phases of salt stress development. This optimum can be extended to any of the indica rice varieties as well. Examination of time courses of relative leaf area showed that the two phases of salt stress development could be clearly demarcated at $100 \mathrm{mM} \mathrm{Na}^{+}$(Figure 6), with the transition from Phase I to Phase II occurring around 10 days after reaching $100 \mathrm{mM} \mathrm{Na}^{+}$. Salinity levels lower than $100 \mathrm{mM} \mathrm{Na}^{+}$did not indicate a clear demarcation of the two phases (in terms of the time course of relative leaf area). On the other hand, at salinity levels above $100 \mathrm{mM} \mathrm{Na}^{+}$, Phase I could not be identified as salt toxicity symptoms appeared even before the salinity was increased up to the target level.

$100 \mathrm{mM} \mathrm{Na}{ }^{+}$was high enough to induce growth reductions and salt toxicity symptoms in the relatively salt-tolerant rice variety At354, which showed itself to have a greater tolerance than even Pokkali. Therefore, the salt tolerance of At354 can be used as the benchmark to develop new tolerant varieties, which preferably need to possess a greater degree of tolerance than At354. It may be argued that levels higher than $100 \mathrm{mM} \mathrm{Na}^{+}$may help identify germplasms with greater tolerance than At354. However, salinity levels greater than $100 \mathrm{mM}$ $\mathrm{Na}^{+}$have the disadvantage of not being able to clearly identify the two phases of salt stress development. As the two-phase model for response to salinity provides a physiological and molecular basis for development of salt tolerant varieties and for identification of genes that are responsible for salt tolerance, the inability to demarcate the two phases would constitute a significant disadvantage. Therefore, until the development of a rice variety, which has significantly greater salt tolerance than At354, $100 \mathrm{mM} \mathrm{Na}^{+}$can be considered as the optimum for varietal screening.

In a study comparing different methods of screening rice varieties for salt tolerance, Aslam et al. (1993) showed that screening at the seedling stage in solution culture at $100 \mathrm{mM} \mathrm{Na}{ }^{+}$produced varietal classification, which was adequately correlated with the corresponding varietal classification based on final yield under field conditions. These results are in agreement with the findings of the present study. However, Aslam et al. (1993) did not distinguish between the two phases of salt stress development. 
Comparison of the optimum salinity level for varietal screening of rice and the point of transition from Phase I to Phase II of salt stress development found in the present study with those found in the other studies on rice and other crops

The extensive body of published work that has reported different aspects of salt tolerance in rice has used a wide range of salinity levels, which were similar, lower or greater than the optimum of $100 \mathrm{mM} \mathrm{Na}^{+}$used in the present study. For example, Koyama et al. (2001) and Flowers et al. (2000) have used the salinity level of 100 $\mathrm{mM} \mathrm{Na}^{+}$for investigating QTLs for salt tolerance in rice. Senadheera et al. (2009) also have used $100 \mathrm{mM} \mathrm{Na}^{+}$ to investigate the differential expression of membrane transporters in rice genotypes differing in salt tolerance. On the other hand, Zeng et al. (2002; 2003) and Zeng (2005) have used salinity levels ranging from 45 to 83 $\mathrm{mM} \mathrm{Na} \mathrm{Na}^{+}$to investigate agronomic and physiological traits related to salt tolerance in rice. Similarly, Walia et al. $(2005 ; 2007)$ have used salinity levels of $70-74$ $\mathrm{mM} \mathrm{Na}{ }^{+}$for comparing salt-induced gene expression profiles of different rice genotypes. In contrast, Zhou et al. (2007) and Sahi et al. (2003) used salinity levels ranging from 150 to $300 \mathrm{mM} \mathrm{Na}{ }^{+}$to analyze salt-induced gene expression and isolate ESTs in rice.

Apart from the influence of the salt sensitivity/ tolerance of the different species and varieties, the transition time taken to move from Phase I to Phase II of salt stress development has been influenced by the growing temperature of the experimental plants. Munns et al. $(1993 ; 1995)$ defined that the point of transition from Phase I to Phase II would be the time at which significant varietal differences appear in the growth reductions as measured in terms of reductions in total biomass or leaf area expansion. For example, in rice growing at temperatures, which are comparable to those of the present study, Aslam et al. (1993) detected significant varietal variation 10 days after imposing a salinity level of $100 \mathrm{mM} \mathrm{Na}^{+}$. This is in agreement with the results of the present study, which showed that the transition occurred 10 days after increasing salinity up to $100 \mathrm{mM} \mathrm{Na}^{+}$(Table 4 \& Figure 6). In contrast, several studies conducted at lower growing temperatures (i.e. 15 $-25^{\circ} \mathrm{C}$ ) on wheat, barley and maize have shown varietal differentiation in the salinity-induced growth reduction, four weeks after imposing salt stress (Schachtman et al., 1991; Fortmeier \& Schubert, 1995; Munns et al., 1995). The longer period taken for transition from Phase I to Phase II was probably the combined result of lower growing temperatures, in which the build-up of salinity in plant tissue would be slower, and the greater salt tolerance of these crop species.

\section{Comparative salt tolerance of At354 and Pokkali}

Results of the present study showed that the Sri Lankan rice variety At354 has a greater degree of salt tolerance than Pokkali, which is the widely-used standard salt tolerant variety. This was evidenced by the slower rate of decline of total plant dry weight of At354 as compared to Pokkali, when salt stress was increased gradually (Figure 1). This resulted in At354 having a higher absolute and relative total dry weight than Pokkali at any given level of salt stress. Absence of any significant effects on shoot-weight ratio (data not shown) showed that salt stress reduced both shoot and root growth in approximately equal proportions. Highly significant correlations between total plant dry weight and shoot dry weight showed that shoot dry weight could also be used as a criterion for evaluating the genotypic variation of salt tolerance in rice.

The lower $\mathrm{Na}^{+}$concentrations of shoots at levels greater than $80 \mathrm{mM} \mathrm{Na}^{+}$, in At354 as compared to Pokkali (Figure 2a) showed that At354 had a greater ability to exclude $\mathrm{Na}^{+}$from its shoot. The higher root $\mathrm{Na}^{+}$ concentrations of At354 (Figure 2b) than that of Pokkali indicated that $\mathrm{Na}$-exclusion was more efficient in At354 at the point of $\mathrm{Na}^{+}$entering the xylem stream (probably the root xylem parenchyma). The Na-exclusion ability of At354 was also shown by its lower shoot:root $\mathrm{Na}^{+}$ concentration ratio (Figure 3). Furthermore, all power functions describing the reduction of total plant dry weight and shoot dry weight with increasing shoot $\mathrm{Na}^{+}$ concentration (Figures 4a \& 5) showed greater salt sensitivity of Pokkali as compared to At354.

The observation in the present study of greater salt tolerance of At354 in comparison to Pokkali is in direct contrast to the findings of Abeysiriwardena (2004) and Subasinghe et al. (2007), which showed greater salt tolerance in Pokkali. However, in both above studies, salt tolerance was quantified based on seed germination after soaking seed in water with a salinity level of $45 \mathrm{dS} \mathrm{m}^{-1}$. In contrast, the quantification of salt tolerance in the present study was based on growth data collected across a range of salinity levels from 20 to $150 \mathrm{mM} \mathrm{Na}$.

In the present study, the time required for appearance of the two visual symptoms of drought and salt toxicity, namely leaf rolling and burning of leaf tip, respectively, showed a negative correlation with the salinity level, with symptoms appearing quicker at higher salinities (Table 4). However, it is notable that visual symptoms of salt toxicity appeared before the detection of a significant acceleration in the reduction of relative leaf area (Table 4). This was probably because of the time 
period that was needed for salt toxicity to affect leaf area. Therefore, determination of the point of transition from Phase I to Phase II of salt stress development should be based on measurements of leaf area or plant biomass rather than on visual symptoms.

\section{CONCLUSION}

The appropriate level of salt stress for screening of hydroponically grown rice varieties for tolerance to salinity in the two phases of salt stress development was found to be $100 \mathrm{mM} \mathrm{Na}^{+}$. The transition from Phase I of salt stress (osmotic stress) development to Phase II of salt stress (salt ion toxicity) development appeared to occur within 10 days after imposing salt stress. With respect to vegetative growth and $\mathrm{Na}^{+}$ion concentration at tissue level, the new improved Sri Lankan rice variety At354 showed a greater salt tolerance than that of the standard salt tolerant variety, Pokkali.

\section{Acknowledgement}

Financial assistance provided by the International Centre for Genetic Engineering and Biotechnology (ICGEB), Italy (Grant Ref. No. CRP/SRI06-01) and the National Science Foundation of Sri Lanka (Grant No. SIDA/2007/ BT/01) is gratefully acknowledged. Technical assistance was provided by Messrs. Danesh Weerasekera, K.B. Attanayake and B.G.G. Wijesooriya of the Department of Crop Science, Faculty of Agriculture, University of Peradeniya.

\section{REFERENCES}

1. Abeysiriwardena D.S. de Z. (2004). A simple screening technique for salinity tolerance in rice: germination rate under stress. International Rice Research Newsletter 29 (2): 78-79.

2. Anonymous (2011). Climate Change Adaptation in Agriculture Sector in Sri Lanka. Available at http:// www.adaptationlearning.net/gallery/climate-changeadaptation-agriculture-sector-undp-sri-lanka, Accessed 22 June 2011.

3. Aslam M., Qureshi R.H. \& Ahmed N. (1993). A rapid screening technique for salt tolerance in rice (Oryza sativa L.). Plant and Soil 150: 99-107.

4. De Costa W.A.J.M. (2009). Impacts of climate change on the long-term variation in the water balance of different rainfall seasons in selected locations of Sri Lanka. Proceedings of the First National Conference on Climate Change and its Impacts on Agriculture, Forestry and Water, 10 - 11 September 2009, Kandy, Sri Lanka, pp. 51-52.

5. De Costa W.A.J.M., Zörb C., Hartung W. \& Schubert S. (2007). Salt resistance is determined by osmotic adjustment and abscisic acid in newly-developed maize (Zea mays
L.) hybrids in the first phase of salt stress. Physiologia Plantarum 131: 311-321.

6. Dissanayake P.K. \& Wijeratne A.W. (2006). Development of a varietal screening procedure for salt tolerance of rice (Oryza sativa L.) varieties at germination stage. The Journal of Agricultural Sciences (Sabaragamuwa) 2 (1): 63-72.

7. Flowers T.J. (2004). Improving crop salt tolerance. Journal of Experimental Botany 55: 307-319.

8. Flowers T.J., Koyama M.L., Flowers S.A., Sudhakar C., Singh K.P. \& Yeo A.R. (2000). QTL: their place in engineering tolerance of rice to salinity. Journal of Experimental Botany 51: 99-106.

9. Flowers T.J. \& Yeo A.R. (1995). Breeding for salinity resistance in crop plants: where next? Australian Journal of Plant Physiology 22: $875-884$.

10. Fortmeier R. \& Schubert S. (1995). Salt tolerance of maize (Zea mays L.): the role of sodium exclusion. Plant, Cell and Environment 18: 1041-1047.

11. Ghassemi F., Jakeman A.J. \& Nix H.A. (1995). Salinisation of Land and Water Resources: Human Causes, Extent, Management and Case Studies. University of New South Wales Press, Sydney, Australia and CAB International, Wallingford, UK.

12. IPCC (2007). Climate Change 2007: Synthesis Report. Contribution of Working Groups I, II and III to the Fourth Assessment Report of the Intergovernmental Panel on Climate Change (eds.) R.K. Pachauri \& A. Reisinger. Intergovernmental Panel for Climate Change, Geneva, Switzerland, p.104.

13. IRRI(2011). Rice Production and Processing. International Rice Research Institute, Los Banos, The Philippines. Available at http://irri.org/about-rice/rice-facts/riceproduction-and-processing, Accessed 22 June 2011.

14. IRRI (2010). IRRI World Rice Statistics. International Rice Research Institute, Los Banos, The Philippines. Available at http://beta.irri.org/solutions/index.php?option $=$ com content\&task=view\&id=250, Accessed 22 June 2011.

15. Koyama M.L., Levesley A., Koebner R.M.D., Flowers T.J. \& Yeo A.R. (2001). Quantitative traits loci for component physiological traits determining salt tolerance in rice. Plant Physiology 125: 406-422.

16. Maas E.V. \& Hoffman G.J. (1977). Crop salt toleranceCurrent assessment. Journal of Irrigation and Drainage Division 103: 115-134.

17. Munns R. (1993). Physiological processes limiting plant growth in saline soils: some dogmas and hypotheses. Plant, Cell and Environment 16: 15-24.

18. Munns R. (2002). Comparative physiology of salt and water stress. Plant, Cell and Environment 25: 239-250.

19. Munns R. (2005). Genes and salt tolerance: bringing them together. New Phytologist 167: 645-663.

20. Munns R., Husain S., Rivelli A.R., James R.A., Condon A.G. (Tony), Lindsay M.P., Lagudah E.S., Schachtman D.P. $\&$ Hare R.A. (2002). Avenues for increasing salt tolerance of crops, and the role of physiologically based selection traits. Plant and Soil 247: 93-105.

21. Munns R. \& James R.A. (2003). Screening methods for salinity tolerance: a case study with tetraploid wheat. Plant and Soil 253: 201-218. 
22. Munns R., James R.A. \& Läuchli A. (2006). Approaches to increasing the salt tolerance of wheat and other cereals. Journal of Experimental Botany 57: 1025-1043.

23. Munns R., Schachtman D.P. \& Condon A.G. (1995). The significance of a two-phase growth response to salinity in wheat and barley. Australian Journal of Plant Physiology 22: 561-569.

24. Munns R. \& Tester M. (2008). Mechanisms of salinity tolerance. Annual Review of Plant Biology 59: 651-681.

25. Pitman M. \& Läuchli A. (2002). Global impact of salinity and agricultural ecosystems. Salinity: Environment-Plants - Molecules (eds. A. Läuchli \& U. Lüttge), pp. 3-20. Kluwer Academci Publishers, The Netherlands.

26. Rawson H.M., Richards R.A. \& Munns R. (1988). An examination of selection criteria for salt tolerance in wheat, barley and triticale genotypes. Australian Journal of Agricultural Research 39: 759-772.

27. Richards R.A. (1983). Should selection for yield in saline regions be made on saline or non-saline soils? Euphytica 32: 431-438.

28. Sahi C., Agarwal M., Reddy M.K., Sopory S.K. \& Grover A. (2003). Isolation and expression analysis of salt stressassociated ESTs from contrasting rice cultivars using a PCR-based subtraction method. Theoretical and Applied Genetics 106: 620-628.

29. Schachtman D.P., Munns R. \& Whitecross M.I. (1991). Variation in sodium exclusion and salt tolerance in Triticum tauschii. Crop Science 31: 992-996.

30. Senadheera P., Singh R.K. \& Maathuis F.J.M. (2009). Differentially-expressed membrane transporters in rice roots may contribute to cultivar dependent salt tolerance. Journal of Experimental Botany 60: 2553-2563.

31. Sirisena D.N. \& Abeysiriwardena D.S. de Z. (2005). Soil water as a medium to screen rice varieties for salinity tolerance. Journal of the Soil Science Society of Sri Lanka 17: (Abstract available at http://www.aic.ca/international/ itpp_docs/Journal\%20SSSSL\%20Vol\%2017.pdf, Accessed 23 June 2011).

32. Sirisena D.N. \& Herath H.M.A. (2009). Productivity enhancement in saline paddy fields in Angiththamkulam Yaya in Sri Lanka: a case study. Proceedings of the $9^{\text {th }}$ International Conference of East and Southeast Asia Federation of Soil Science Societies. 27-28 October 2009, Seoul, Korea, pp. 507-508.

33. Subasinghe A., Nissanka N.A.A.S.P. \& Weerakoon W.M.W. (2007). Identification of salt tolerant rice varieties at the seed germination stage and its relationship to seed husk thickness and ion absorption. Tropical Agricultural
Research 19: 219-228.

34. Szabolcs I. (1994). Soils and salinisation. Handbook of Plant and Crop Stress, $1^{\text {st }}$ edition (ed. M. Pessarakli), pp. 3-11. Marcel Dekker, New York, USA.

35. USDA-ARS (2008). Research Databases. Bibliography on Salt Tolerance. George E. Brown, Jr. Salinity Laboratory, United States Department of Agriculture Research Service, California, USA. Available at http://www.ars.usda.gov/ Services/docs.htm?docid=8908, Accessed 22 June 2011.

36. Van Ranst E., Verloo M., Demeyer A. \& Pauwels J.M. (1999). Manual for the Soil Chemistry and Fertility Laboratory: Analytical Methods for Soils and Plants, Equipment and Management of Consumables. International Training Centre for Post-Graduate Soil Scientists. Gent, Belgium.

37. Walia H., Wilson C., Condamine P., Liu X., Ismail A.M., Zeng L., Wanamaker S.I., Mandal J., Xu J., Cui X. \& Close T.J. (2005). Comparative transcriptional profiling of two contrasting rice genotypes under salinity stress during the vegetative growth stage. Plant Physiology 139: 822-835.

38. Walia H., Wilson C., Zeng L., Ismail A.M., Condamine P., \& Close T.J. (2007). Genome-wide transcriptional analysis of salinity stressed japonica and indica rice genotypes during panicle initiation stage. Plant Molecular Biology 63: 609-623.

39. Yoshida S. (1981). Fundamentals of Rice Crop Science. Los Banos, Philippines.

40. Yoshida S., Forno D.A., Cock J.H. \& Gomez K.A. (1972) Laboratory Manual for Physiological Studies of Rice. International Rice Research Institute, Los Banos, Philippines, p. 54.

41. Zeng L. (2005). Exploration of relationships between physiological parameters and growth performance of rice (Oryza sativa L.) seedlings under salinity stress using multivariate analysis. Plant and Soil 268: 51-59.

42. Zeng L., Shannon M.C. \& Grieve C.M. (2002). Evaluation of salt tolerance in rice genotypes by multiple agronomic parameters. Euphytica 127: 235-245.

43. Zeng L., Poss J.A., Wilson C., Draz A-S.E., Gregorio G.B. \& Grieve C.M. (2003). Evaluation of salt tolerance in rice genotypes by physiological characters. Euphytica 129: 281-292.

44. Zhou J., Wang X., Jiao Y., Qin Y., Liu X., He K., Chen C., Ma L., Wang J., Xiong L., Zhang Q., Fan L. \& Deng X.W. (2007). Global genome expression analysis of rice in response to drought and high salinity stresses in shoot, flag leaf and panicle. Plant Molecular Biology 63: 591-608. 